\title{
Myths and Realities Concerning Task Based Language Teaching: A Discussion
}

\author{
Anjali Thakur
}

\begin{abstract}
This paper discusses about the myths and the realities related to the Task Based Language Teaching. There are myths related to inclusion of grammar in teaching language, tasks should be focused or not, focuses on process, comparison with traditional approach, etc. Author discusses these myths with realities.
\end{abstract}

Keywords — Task Based Language Teaching, teaching language, Tasks

\section{INTRODUCTION}

Task Based Language Teaching (TBLT) belongs to the group of Task Based Instruction (TBI), Task Based Teaching (TBT) and Task Based Language Learning (TBLL). There are many myths related to TBLT which are developed down the lane due to perceptions. This paper discusses various myths related to TBLT and reality behind them. These myths came up while discussing approaches for teaching language during the workshop conducted at Dharmsinh Desai University, India.

Task-Based Language Teaching (TBLT) is an outcome of 'Communicative Language Teaching'. It is an approach for teaching L2 (Second Language) by engaging and providing learners the opportunities to experiment and explore the target language through series of tasks. These tasks are specially designed to engage them in the 'authentic, practical and functional' use of language for meaningful purposes. According to Ellis the aim of TBLT is 'to enable the learners to acquire new linguistic knowledge' and 'to proceduralize their existing knowledge.' It aims to improve the language competence by stimulating their 'natural desire' for learning the language through the challenge of completing a meaningful task [1] [2]. TBLT is an 'approach based on the use of tasks as the core unit of planning and instructions in language teaching' [3].

\section{MYTHS \& REALITIES}

TBLT do not 'Focus on Form' but 'Focus on Meaning' only.

TBLT's primary focus is on 'meaning', but it does not completely ignore 'form'. According to Jane and David, "Most current approaches to TBT certainly recognise the importance

Anjali Thakur

Dharmsinh Desai University, Nadiad

India of grammar. Today task-based activities are almost always followed by one or more form-focused activity." "There is certainly a place for a focus on specified forms in a task-based approach. But form should be subordinate to meaning and, for this reason, should come after rather than before a task." [4]. They believe that after 'focus on meaning' the next most important is 'focus on language'- learners working with meaning and are thinking about language on their initiative, independently of the teacher. Focus on Language can take place during any stage of task cycle (task $\rightarrow$ planning $\rightarrow$ report) but 'focus on form' will take place only at the last stage. "Task-based language teaching ... is an attempt to harness the benefits of a focus on meaning via adoption of an analytic syllabus, while simultaneously, through use of focus on form (not forms), to deal with its known shortcomings, particularly rate of development and incompleteness where grammatical accuracy is concerned." [5]

"The meaningful use of language will necessarily imply the establishment of relevant form-meaning mappings; the learner will need to manipulate and thus pay at least some (conscious or unconscious) attention to form." [6]

Rod Ellis believes that focus on form should take place throughout the task-cycle, whether the task is 'focused' or 'unfocused'. "Both Willis and Skehan emphasise the need to attend to form in a task-based lesson...various options at the pre-task, during-task, and post-task phases of a lesson have been proposed for achieving such a focus. In particular, it has been emphasised that attention to form is both possible and beneficial in the during-task phase and need not conflict with Principle 6 (students are primarily focused on meaning when they perform a task)." [7]. But, on the other hand, Skehan, Nunan, Jack C. Richards and Theodore S. Rodgers negate the role of focus on form in tasks designed for language learning. According to Richards and Rodgers "Engaging learners in task work provides a better context for the activation of learning processes than form-focused activities ..." [8]

Skehan definies "Tasks... are activities which have meaning as their primary focus", whereas for Nunan "the communicative task [is] a piece of classroom work which involves learners in comprehending, manipulating, producing or interacting in the target language while their attention is principally focused on meaning rather than form." [3] 
The debate is on whether should there be 'Focus on form' in TBLT or not? To what extent it should be there? At which phase it should be introduced? Should it be there in all the phases?

According to Koen and Nora, "focus on form may be elegantly integrated in the during-task phase, for instance when students face comprehension or language production problems. If, for instance, students have to process the information in a particular text, but fail to do so because they do not know the meaning of certain essential words, explicit focus on the meaning of these words may be of immediate use. Likewise, short focus on form during the pre-task phase may contribute to the learner's noticing the linguistic forms while performing the task, while post-task focus on form may add to restructuring, automatizing and consciously attending to language forms that were used in the previous phase." [9]

It should be introduced in such a manner that subconsciously they acquire it. If it is induced in the pretask then for the entire task cycle they will be consciously concentrating on Form instead of meaning. And if it is inserted during the task, then a flow of thought will get disturbed which will directly affect the flow of language.

\section{A. Task is the heart of TBLT.}

The main component of Task-Based Language Teaching is 'Task'. For Long, 1985 "Tasks are the things people will tell you they do if you ask them and they are not applied, linguists". Whereas for Breen, 1989 "task can be a brief practice exercise or a more complex work plan that requires spontaneous communication of meaning". The definition of 'task' is getting more precise when Prabhu, 1987 defines it as 'an activity which required learners to arrive at an outcome from given information through some process of thought, and which allowed teachers to control and regulate that process'. According to Ellis [7], Skehan in 1996 clarifies what is activity when he says that "A task is an activity in which: meaning is primary; there is some sort of relationship to the real world; task completion has some priority; and the assessment of task performance in terms of task outcome". And in 2001, Bygate, Skehan, and Swain modify the definition 'A task is an activity which requires learners to use language, with emphasis on meaning, to attain an objective.' [7]. Further, Rod Ellis [7] narrow downs the definition "Tasks' are activities that call for primarily meaning-focused language use.'

If 'task' is the heart than 'work-plan' is the brain of TBLT. Workplan makes any activity more systematic leading towards the goal: with work-plan, any activity turns into a task. Moreover, it makes task distinctive from exercise. Task (heart) fails if there is no defined framework/task design/procedure.

\section{B. Tasks should always be 'Focused Tasks'.}

According to Nunan [2], "A focused task is one in which a particular structure is required in order for a task to be completed. An unfocused task is one in which the learners are able to use any linguistic resources at their disposal in order to complete the task." According to Rod Ellis [7], "Unfocused tasks may predispose learners to choose from a range of forms, but they are not designed with the use of a specific form in mind. In contrast, focused tasks aim to induce learners to process, receptively or productively, some particular linguistic feature, for example, a grammatical structure."

Technical writing is full of formats, be it letter or minutes or notice or circular or report. So, in this case, the tasks will be focused. The focus will not be on grammar but the format or structure of the 'type' of write-up. We can call it 'Semifocused', which will 'Focus' on formats but 'Unfocused' on linguistic features.

Not focusing on grammar or form does not mean ignoring them entirely; because at the end grammar gives the meaning to the content and the whole meaning changes if used incorrectly. All the TBLT scholars have talked about inducing focus on form at one or the other phase of the tasks. Willis and Willis do not believe in the concept of 'focused' tasks so much so that there is no mention of the concept 'Focused and Unfocused tasks' in their book 'Doing Task-based Teaching' published in 2007. "One feature of TBL (task-based learning), therefore, is that learners carrying out a task are free to use any language they can to achieve the outcomes: language forms are not prescribed in advance." [2]. Jane and Dave [4] believe that learners should be allowed to explore the language (focus on form) according to the requirement of it for expressing the meaning. But, they do believe that focus on form can be at the end of the sequence.

The reasons behind this they gave are:

i. It helps learners to make sense of the language they have experienced.

ii. It highlights language they are likely to experience in the future.

iii. It provides motivation.

For them, Focus on meaning is when participants are concerned with communication. Focus on language is where learners pause in the course of a meaning-focused activity to think for themselves how best to express what they want to say, or a teacher takes part in the interaction and acts as a facilitator by rephrasing or clarifying learner language. And, Focus on form is when one or more lexical or grammatical structures are isolated and specified for study, or in which the teacher comments on student's language by drawing attention to problems.

\section{Rejects the traditional approach.}

Language is a tool for communication and communication takes place in the real world. In traditional approach language learning takes place in isolation. TBLT believes that if a language is to be used in the real world for communication, then learners have to communicate the way they are going to do in the real world.

Rod Ellis has listed out the difference between traditional form-focused pedagogy and Task-based pedagogy: [7] 
TABLE I

COMPARISON OF TRADITIONAL PEDAGOGY AND TASK-BASED PEDAGOGY

\begin{tabular}{|c|c|c|}
\hline & $\begin{array}{c}\text { Traditional form-focused } \\
\text { pedagogy }\end{array}$ & Task-based pedagogy \\
\hline 1. & $\begin{array}{l}\text { Rigid discourse structure } \\
\text { consisting of IRF (initiate- } \\
\text { respond-feedback) exchanges }\end{array}$ & $\begin{array}{l}\text { Loose discourse structure } \\
\text { comprising of adjacency pairs }\end{array}$ \\
\hline 2. & $\begin{array}{c}\text { Teacher controls topic } \\
\text { development }\end{array}$ & $\begin{array}{c}\text { Students able to control topic } \\
\text { development }\end{array}$ \\
\hline 3. & $\begin{array}{c}\text { The teacher regulates turn- } \\
\text { taking }\end{array}$ & $\begin{array}{c}\text { Turn-taking is controlled by the } \\
\text { same rules that govern everyday } \\
\text { conversation, i.e. speakers can } \\
\text { self-select }\end{array}$ \\
\hline 4. & $\begin{array}{c}\text { Display questions, i.e. questions } \\
\text { that the questioner already } \\
\text { knows the answer to }\end{array}$ & $\begin{array}{l}\text { Use of referential questions, i.e. } \\
\text { questions that the questioner } \\
\text { does not know the answer to }\end{array}$ \\
\hline 5. & $\begin{array}{l}\text { Students are placed in a } \\
\text { responding role and } \\
\text { consequently perform a limited } \\
\text { range of language functions }\end{array}$ & $\begin{array}{c}\text { Students function in both } \\
\text { initiating and responding roles } \\
\text { and thus display a wide range of } \\
\text { language functions, e.g. asking for } \\
\text { and giving information, agreeing } \\
\text { and disagreeing, instructing }\end{array}$ \\
\hline 6. & $\begin{array}{l}\text { Little need or opportunity to } \\
\text { negotiate meaning }\end{array}$ & $\begin{array}{c}\text { Opportunities to negotiate } \\
\text { meaning when communication } \\
\text { problems arise }\end{array}$ \\
\hline 7. & $\begin{array}{l}\text { Scaffolding primarily directs at } \\
\text { enabling students to produce } \\
\text { correct sentences }\end{array}$ & $\begin{array}{l}\text { Scaffolding directed mainly at } \\
\text { allowing the students to say what } \\
\text { they want to say }\end{array}$ \\
\hline 8. & $\begin{array}{l}\text { Form-focused feedback, i.e. the } \\
\text { teacher responds implicitly or } \\
\text { explicitly to the correctness of } \\
\text { students' utterances }\end{array}$ & $\begin{array}{l}\text { Content-focused feedback, i.e. the } \\
\text { teacher responds to the message } \\
\text { content of the students' } \\
\text { utterances }\end{array}$ \\
\hline 9. & $\begin{array}{l}\text { Echoing, i.e. the teacher } \\
\text { repeats what a student has said } \\
\text { for the benefit of the whole } \\
\text { class }\end{array}$ & $\begin{array}{c}\text { Repetition, i.e. a student elects to } \\
\text { repeat something another student } \\
\text { or the teacher has told as private } \\
\text { speech or to establish } \\
\text { intersubjectivity }\end{array}$ \\
\hline
\end{tabular}

\section{TBLT is product driven.}

The approach is product driven when it is 'present-practiseproduce' (PPP); where language item is first presented to the learners then this item is practiced in a controlled manner in the form of exercises, and finally, opportunities for using the item in free language production are provided. In this production stage tasks have been employed that too 'grammar tasks'. Note: according to SLA research language is not acquired in this manner. Instead of acquiring language learners 'construct a series of systems, known as inter-languages.

Language is a whole entity; to acquire it one need not divide it into different components like grammar and other linguistic elements. It has to be learnt as a whole the way it is used in a real world. When a child is acquiring L1 at that time the speakers do not divide the language, in the same manner, an L2 learner should also get the real-world experience to learn the language.

TBLT it keeps in mind this and designs the real world or near to real-world tasks. In a product-driven approach, the task is at the end while the heart of TBLT is a task. Tasks are the process:

(i) Pre-task, (ii) Task and (iii) Post task. In TBLT the primary focus is not on grammar, but it is on using of the language.

\section{E. It is an effortless approach}

It seems to be an easy task for the observers, but a teacher has to take the pain to design the task. After finalising the work plan, a teacher understands the level and needs of students, things become easy but not entirely. Because it is a learnercentric approach teacher may have to modify the task on the spot while the task is going on. A teacher has to be very active and alert; the impromptu situation may arise.

Definitely, for students, it is a relaxed approach to learning and very useful giving them the real-life experiences.

\section{F. Teachers do not have much responsibility in comparison to other approaches.}

It is not all about what it happens in the traditional classroom where for an hour it is the only teacher who speaks and writes on the board. The onlooker may find that in taskbased language teaching $99 \%$ of the time in the classroom students are busy executing the task and teacher has nothing to do, but it is not so. In TBLT teacher play many roles like:

i. Leader and organiser of discussion

ii. Manager of group/pair work

iii. Facilitator

iv. Motivator

v. Language 'knower' and adviser

vi. Language teacher

vii. Selector and Sequencer of Tasks

viii. Preparing Learners for Tasks

ix. Consciousness-raising

The job of the teacher starts firstly with gauging the need and level of the students to deciding the goal/objective of the task. Secondly, executing the objective by designing task keeping in mind Pretask activities, Task activity/task cycle (task $\rightarrow$ planning $\rightarrow$ report), Post task activities that are 'The language focus' (analysis and practice).

\section{G. Any activity can be considered as a 'task'.}

Anything we do can be called 'activity' like planting the sapling, cooking food, or students coping from the broad. But, 'Task' refers to a range of work-plan which has the overall purpose of facilitating language learning - from the short and straightforward exercise type to more complex and lengthy activities such as group problem-solving or simulations and decision-making. According to Skehan "classroom task should relate in some way to an activity in the real world.

The task is an activity which:

i. Engages learners' interest

ii. A primary focus is on the meaning

iii. There is an outcome

iv. Success is judged concerning the outcome

v. Completion is a priority

vi. It relates to real-world activities

It is possible that not all the tasks will give the real-world feel. If you see engineering students will not get the exact feel 
of professional life in their classroom, but they may get exposed to real life socialising.

\section{H. Learners decide what they want to learn.}

TBLT is a learner-centric approach, but it is not the learner who knows what has to be done. Even if they know what is needed, it is a teacher who knows how to fulfill that need. It is also believed that teaching takes place according to the mood of the learners. Any experienced teacher would say if we do that then learning will be very slow and in some cases almost nil. The teacher has to invoke the interest of the students in learning, and here the well-planned task comes to the rescue.

In TBLT learner plays the role of [6]

$$
\text { i. Group Participant }
$$

ii. Monitor

iii. Risk-taker and innovator

iv. Negotiator

\section{Tasks are chunks.}

No. "task-based syllabuses do not chop up language into small pieces, but take holistic, functional and communicative 'tasks', rather than any specific linguistic item, as the basic unit for design of educational activity" [6]

\section{J. TBLT ignores syllabus designed under the academic curriculum}

According to David Nunan [3], TBLT syllabus specifies that the tasks should be carried out by learners within a program. A syllabus might specify two types of tasks:

i. Real-world tasks, which are designed to practice or rehearse those tasks that are found to be important in a needs analysis and turn out to be essential and useful in the real world.

ii. Pedagogical tasks, which have a psycholinguistic basis in SLA theory and research but do not necessarily, reflect real-world tasks.

\section{CONCLUSION}

Thus, from this discussion, we can conclude that TaskBased Language Teaching (TBLT) is an outcome of 'Communicative Language Teaching'. It is an approach for teaching L2 (Second Language) by engaging and providing learners with the opportunities to experiment and explore the target language through series of tasks. These tasks are specially designed to engage them in the 'authentic, practical and functional' use of language for meaningful purposes. According to Ellis the aim of TBLT is 'to enable the learners to acquire new linguistic knowledge' and 'to proceduralize their existing knowledge.' It aims to improve the language competence by stimulating their 'natural desire' for learning the language through the challenge of completing a meaningful task (Ellis, 2007, Nunan, 2005). TBLT is an 'approach based on the use of tasks as the core unit of planning and instructions in language teaching' (Richards \& Rodgers, 2001).

According to Kris Van den Branden (2006), in task-based language teaching, the 'task' is a core element of analysis. It has three levels: goal, i.e. 'syllabus,' educational activities, i.e. 'methodology' and assessment. It is important to understand the reason behind learning of the second language and what they expect from this learning. For this purpose 'target tasks' are designed.

In TBLT learners are the essential elements and not the teacher; it is 'learner-centric approach.' Here a learner does not work in isolation; rather learner is group participant, a risk taker who is also monitor and innovator. Here the teacher carefully selects, puts in sequence and designs the tasks using 'pedagogical material' and 'Realia' like newspapers, television, internet and also maybe textbooks and journals and their campus activities.

\section{REFERENCES}

[1] R. Ellis, Planning and Task Performance in Second Language , Amsterdam: John Benjamins Publishing Company, 2005.

[2] D. Nunan, Task-Based Language Teaching, New York: Cambridge Univeristy Press, 2004 https://doi.org/10.1017/CBO9780511667336

[3] C. Richards and T. S. Rodgers, Approaches and Methods in Language Teaching, New York: Cambridge University Press, 2001, p. 223. https://doi.org/10.1017/CBO9780511667305

[4] D. Willis and J. Willis, Doing Task-based Teaching, New York: Oxford University Press, 2015.

[5] Long and J. Norris, "Task-based teaching and assessment," in TaskBased Language Education: From theory to practice, New York, Cambridge University Press, 2000, p. 9.

[6] K. v. d. Branden, Task-Based Language Education: from theory to practice, K. v. d. Branden, Ed., New York: Cambridge University Press, 2006, p. 10 . https://doi.org/10.1017/CBO9780511667282

[7] R. Ellis, Task-based Language Learning and Teaching, New York: Oxford University Press, 2014, p. 253.

[8] J. C. Richards and T. S. Rodgers, Approaches and Methods in Language Teaching, Cambridge University Press, 2001, p. 224. https://doi.org/10.1017/CBO9780511667305

[9] V. G. K. and N. Bogaert, "Developing language tasks for primary and secondary education," in Task-Based Language Education: From Theory to Practice, New York, Cambridge University Press, 2006, pp. 76-105.

[10] C. S. Wiseman, "A Comparison of the Performance of Analytic vs. Holistic," Iranian Journal of Language Testing,, vol. 2, no. 1, pp. 59-92, March 2012.

[11] J. Willis, A Framework of Task-Based Learning, Longman, 1996.

[12] D. Willis and J. Willis, "Task-based language learning," in Task-based language teaching, Cambridge, Cambridge University Press, 2001. https://doi.org/10.1017/CBO9780511667206.026

[13] A.J. Rutherfoord, Basic Communication Skills for Technology, New Delhi: Pearson Education, Inc., 2013.

[14] J. Riemer, "Communication Skills for the 21st Century Engineer," Global J. of Engng. Educ., vol. 11, no. 1, pp. 89-100, 2007.

[15] S. Rajan, Methodology of Teaching Science: Always learning, Pearson Education India, 2012, p. 184.

[16] S. Prabhu, "Second Language Pedagogy," in Approaches and Methods in Language Teaching, Oxford University, 1987, p. 233.

[17] G. Mitra, "Evaluation - In the Teaching and Learning Process," in Educational Evaluation, Pune, Symbiosis Centre for Distance Learning, 2009 , p. 4.

[18] Gronlund, "Measurement and Evaluation in Education," in Task-based Language Teaching, Cambridge, Cambridge University Press, 1981, p. 139 
https://doi.org/10.2307/3587079

[19] S. Fotos and R. Ellis, "Communicating About Grammar: A Task-Based Approach," in Task-based Language Teaching, Cambridge, Cambridge University Press, 1991.

[20] R. Ellis, "Task-based language Teaching and Learning," in Task-based Language Teaching, Cambridge, Cambridge University Press, 2001. https://doi.org/10.1017/CBO9780511667282.008

[21] M. Colpin and S. Gysen, "Developing and introducing task-based language tests," in Task-Based Language Education, Cambridge, Cambridge University Press, 2006, p. 151.

[22] S. Adams, "The 10 Skills Employers Most Want In 2015 Graduates," 11 December 2014. [Online]. Available: http://www.forbes.com/sites/susanadams/2014/11/12/the-10-skillsemployers-most-want-in-2015-graduates/.

[23] Waterloo Centre for the Advancement of Co-operative Education (WatCACE), "The Role of the Work Report in Co-operative Education at the University of Waterloo," University of Waterloo, Waterloo, 2004.

[24] "The Role of Higher Education in Career Development: Employer Perceptions," The Chronicle of Higher Education and American Public Media's Marketplace, America, 2012.

[25] National Association of Colleges and Employers (NACE), "Job Outlook," Bethlehem, 2013

[26] Harth Research Associates, "It Takes More Than a Major: Employer Priorities for College Learning and Student Success," The Association of American Colleges and Universities, Washington, 2013.

[27] INDIAN INSTITUTE OF TECHNOLOGY GUWAHATI, "GUIDELINES FOR B.TECH PROJECT Department of Mechanical Engineering," [Online]. Available: http://www.iitg.ac.in/mech/files/misc/BTP\%20report\%20preparation\%2 oguidelines.pdf.

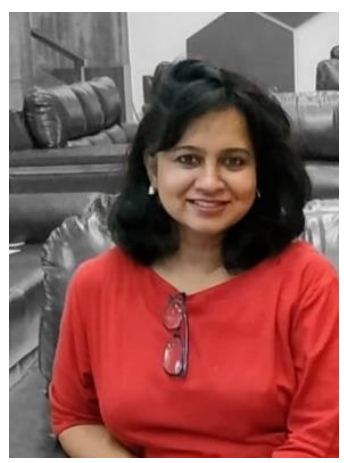

